\title{
The Impact of job stress: An imperative insight into the Banking sector
}

\author{
Aliya Ahmad Shaikh \\ MS Scholar, Department of Business Administration \\ NCBA\&E, Bahawalpur, Pakistan
}

Memoona Akram

MS Scholar, Department of Business Administration

NCBA\&E, Bahawalpur, Pakistan

\section{Muhammad Rizwan}

Lecturer, Department of Management Sciences,

The Islamia University of Bahawalpur, Pakistan

Email: rizwan.arshad@iub.edu.pk

Shakeela Kousar

MS Scholar, Department of Business Administration

NCBA\&E, Bahawalpur, Pakistan

Muneeb Malik

MS Scholar, Department of Business Administration

NCBA\&E, Bahawalpur, Pakistan

Accepted: September 13, 2013 DOI: 10.5296/jpag.v3i3.6223

\begin{abstract}
In this era of stiff competition employee performance is the key driving force for organizational success, at the same time pressure become the part $\&$ parcel in organizations
\end{abstract}


for keeping employees motivated to win the competitive race. But undue pressure can causes stress which undermines performance .Stress is ubiquitous phenomenon and a straining condition that has a negative impact on an individual's physical, physiological, personal and family life. Now days, due to the rapid changes and intense competition the banking sector employees are among the victims of stress. This study has been carried out to investigate the causes of job stress (job demand, work life conflict), the impact of job stress on employee job behaviours (job performance, job satisfaction) and outcomes of job stress (turnover intention, burnout) and also the relationship between organizational commitment and job satisfaction is explored. A questionnaire(scales having 38 items) measured against 5 point Likert-type scale is used to evaluate the relationship among variables of interest which analyzed through statistical tests of regression, correlation and reliability of the measures was confirmed. The regression analysis results show that there is no significant relationship among job demands, Job stress and job performance, but variables of job demand, work life conflict, and job stress has a significant positive relationship with each other and same is the case for turnover intention, burnout \& job satisfaction which depend upon the stress faced by the banking employees .There is significant positive correlation between job commitment and Job satisfaction. Theoretical implication of this study will be for diverse organizations for understanding the factors that are causing the stress among employees and how to get rid from this evil of stress to increase employee satisfaction, performance and commitment. Recommendations to reduce the stress level are also discussed and focus of future studies is mentioned.

Keywords: Job stress, Job Performance, Job satisfaction, Turnover Intention, Burnout, Organizational commitment, Work life imbalance

\section{Introduction}

Employees are the integral part of an organizational. The industrial psychology has always asserted the significance of understanding and evolving the employees for the sake of the organizational wellbeing as a whole. Emphasizing the employee's concerns, Gaither, Doucette \& Pederson (2008) asserted the significance of understanding interpersonal (individual factors) and non interpersonal aspects (like organizational environment and extra role factors) of the job so that the employees may not face stress of any kind and ultimately turnout to be committed and potential employees in the long run.

The practice of a profession can be satisfying or stressful (Gaither et al., 2008). Ismail, Yao \& Yunus (2009) stated that stress has been originally derived from the Latin word 'stingere' which refers to hardships. Thus Stress at the organization is termed as 'occupational stress/job stress'. Generally Stress is the 'human resistance' to the external forces arising commonly in the domains of: Stress as stimulation---threats, Stress as reaction---in response to a particular event, Stress as a relation-due to interaction with the external environment (Michael, Court $\&$ Petal, 2009). The causes and effects of job stress in any field can be analysed by its antecedents and consequences.

Exploring various constructs relevant to 'job stress' Chen \& Silverthorne (2008) regarded the impact of job stress on 'Job performance' which is the measure of employee's productivity in 
the form of three types (i) rate of output over time reported by employees (ii) the external appraisal or rating for productivity (iii) the self appraisal for achievement. Employees' job performance is traced to the key construct of 'Job satisfaction'. Examining the cause and effect relation of job stress and job satisfaction Rizwan et al. (2010) realized that job stress lessens the job satisfaction and effectiveness of employee's output. Thus Job satisfaction is the key component which further leads to enthusiasm, promotion, extraordinary levels of achievement and performance of employees. In determination of job satisfaction Gaither et al. (2008) conceptualized 'Organizational commitment' as the affective component with which employees feel proud to be involved, associated and identified with a particular organization.

Asserting the general facets of job stress arising in the form of physical and physiological stress Rizwan et al. (2010) further explored 'behavioural stress' to be arising when the individuals react and interact at workplace; it is depicted in the form of symptoms like interpersonal conflict, emotional conflicts, diminishing performance, boredom and creativity issues. The state of Role conflict results into 'role ambiguity' which arises when there is conceptual discrepancy in the required job tasks and the content performed, employees are not awaked about their role requirements, lack sound direction, may not have enough information to full fill the role requirements due to which employees misadjust in the organization's complex structure (Moncrief et al., 1997; Shropshire \& Kadlec, 2012; Michael, Court \& Petal, 2009).

When the employment arrangement is such that there is no clear boundary line established between work and home then 'Work-family conflicts' arise and hinder an employee's performance (Shropshire \& Kadlec, 2012). Furthermore, Rizwan et al. (2010) inferred that 'role-overload' also stimulates job stress. The work-overload arises when there is too much task piled up, work is additional or unpaid, and runs counter to the employees' skills and interests and when the specialized training is not provided for various tasks.

The consequences of job stress determined by Shropshire \& Kadlec (2012) state that the affective reaction to the stressors like role ambiguity, role conflict, compensation loopholes, lack of autonomy, and high job demands appears in the form of 'Employee Burnout'. This is the condition in which employees are completely deprived of cognition and motivation and intend to switch the organization. 'Intention to leave' is largely embedded in the fusion of job insecurity, job stress and burnout which ultimately results into turnover. 'Turnover' is the end state in which chronic pressure depletes away all the energy (emotional and physical) and its consequences turn out to be as dissatisfaction from job, low organizational commitment, a huge intention to leave and career change especially for high demanding professions like nursing and finance.

All of the above factors cause incongruity in job satisfaction; however nowadays they basically are the result of changing organizational policies, procedures, infrastructures, reorganizing value chain process, hierarchy, pressures of innovation and profitability, coping with contemporary work environment and many others; which ultimately shrink the job satisfaction scale of employees (Moncrief et al., 1997). As Shropshire \& Kadlec (2012) contributed that the events like mergers, acquisitions, rightsizing, new technology and 
industry pressures result into perceived distress among employees which ultimately ruins the psychological contract of employees with the organization and they feel threatened.

Stress is the multifaceted construct and there is a vast literature on it. However this study observes the affects of stress in the privatized banking sector of Pakistan, which is exponentially growing industry of Pakistan. To produce the synergy effect in the Banking industry surmount; it is extremely essential to bring flexibility in the threshold by which organizational employees encounter job stress; as stress exerts compounding affects upon the banking sector's employees' performance. This research can be a significant implication for retaining and maintaining the performance of the banking sector's employees in today's impulsive environment.

\section{Literature Review}

The term stress was initially originated from the field of physics and later on got embedded in the field of psychology (Michael, Court \& Petal, 2009). Stress is basically the uncontrollable adverse work experience when there is no conformance in the state desired and the state actually perceived (Moncrief et al., 1997; Rizwan et al., 2010), employee's realize the work pressure to be beyond their capabilities (Shropshire \& Kadlec, 2012), it affects the emotional and physiological state of individuals aversively due to undesirable circumstances in their instant workplace ambience (Lawrence \& Kacmar, 2012; Michael, Court \& Petal, 2009).

Generally, Prior to the stage at which job stress turns harmful; there exists a stage of 'Eustress' which is essential to bring the desirable consequences (Wu, 2011; Lawrence \& Kacmar, 2012) and this optimum stress level boosts the immune system and creativity within employees (Rizwan et al, 2010; Shropshire \& Kadlec, 2012). Eustress arises when the intensity of stress is from moderate to low, conversely 'Distress' arises when the intensity of stress arises and provokes an individual's self regulatory body, physically and physiologically. In fact Distress occurs when the employees do not possess the required attitude, knowledge skills and abilities to cope up with the overwhelming work pressures and demand which result into negative outcomes like absenteeism, low organizational commitment, turnover, emotional frustration, deteriorating health and the career change eventually (Ismail, Yao \& Yunus, 2009).

Focussing upon the organizational job stress; occupational and the individual stressors in terms of short and the long run affects observed in the form of psychological stress are seen as emotional reactions in the form of job alienation, fatigue, aggression, burnout and nervousness (Ismail, Yao \& Yunus, 2009), demotivation, overt depressive reactions and inability of employees to fulfil assigned tasks (Rizwan et al., 2010), anxiety, fear of failure, annoyance and dread (Wu, 2011). And Physiological stress is observed in the form of migraine, digestion problems, back and head ache, heart palpitations, disturbance of internal biological clock for sleep, muscle cramps and the routine disorders of sleep, eating and drinking (Ismail, Yao \& Yunus, 2009), gastrointestinal disorders, insomnia and dermatological disorders (Rizwan et al., 2010), coronary heart failure, frustration, exhaustion and fatigue (Gaither et al., 2008). 


\section{$\triangle$ Macrothink}

The severity of stress can result into chronic death as well. Moncrief et al. (1997) traced the outbreak of physical illness from work initially to the Japanese phenomenon 'Karoushi' or death from over work. This 'Stress death' is caused by long term side effects of working in a situation where one feels vulnerable and trapped to overcome a situation by defending or adapting a change. $\mathrm{Wu}$ (2011) asserted that stress does not only originate from the pressure puff itself, rather it also arises from the perception of pressure itself. This stress deprives an individual from time and energy and leads to loss of quantity and quality output.

\subsection{Job demand}

Gaither et al. (2008) stated that work load/job demand is the uncertainty associated with one's output; like mismatch of performance with real requirements of job which mostly arises due to time constraints, unrealistic demands and ambiguous role expectations. Adding to the same concept Michael, Court \& Petal (2009) advocated their findings implied that 'role overload' arises when there is severe incongruity between the role demands and the quality and quantity of time, resources and capability available to fulfil it. The behavioural outcomes of huge job demand and overload results in the absenteeism and sick leaves, exhaustion and anxiety, concentration and focus issues, work accidents, burnout and withdrawal behaviours like early retirements, and poses many such threats for the organization. It is explored through the 'work over load index' that new employee faces more stress due to low experience as compared to the veterans. Moreover the resource requirements like time frame were identified as major stressors which impact the quality output. Upon this index Stress was observed to be fluctuating across the start middle and the end of the year. Kim et al. (2009) cited Karatepe et al. (2006) who surmised that gender differences moderate the role of role conflict and job satisfaction in banking industry where role expectations(job demand) are much diversified. Considering the unique organizational contexts like services industry, Kim et al. (2009) articulated the detrimental and contingent affect of job stress in the construct of hospitality industry i.e. Hotel industry. Such industries in which employees are assigned with dynamic and multiple roles with various ranks and in which there is more inter-departmental collaboration; are found to more likely confront with the counterproductive stress strains (psychological, behavioural and psychological).

\section{H1: Job demand positively affects the job stress.}

\subsection{Work life conflict}

In addition to role conflict, role ambiguity and work overload (in the organizational environment), Gaither et al. (2008) concluded that the 'extra role factor' is an important construct which is manifested in the form of work home conflict. Work home conflict arises when the work and non work activities overlap. Continuing demand and the non work factors is very important factor which influences the likelihood of leaving one's employer. Shropshire \& Kadlec (2012) asserted the significance of inflexibility in the working schedule like $24 / 7$ presence for work in many IT related fields like finance, healthcare, engineering and insurance where the IT industry is facing workforce attrition regarding career exodus. The determinants of volunteer career change intention are highly associated with stress, job insecurity and burnout. Certain roles like 'Boundary spanning role' of sales people is an 
'added stress' itself, as they have a huge workload and have to answer to multiple parties (Moncrief et al., 1997).

Chen \& Kao (2011) documented that working environment of specialized fields like flight attendants requires huge emotional work like dealing with annoying passengers, working through extensive hours with low decision latitude. Such circumstances report stress factor antecedents as work-to-family and family-to-work conflict while the turnover intention, absenteeism, job satisfaction and organizational commitment issues happen as consequences. Such 'emotional labour' reports the family-work conflicts (family-to-work and work-to-family) to increase job stress which impacts job satisfaction negatively. Finally the consequence of job dissatisfaction flows to lower organizational commitment which eventually increases the chances of turnover intention.

\section{H2: Work life conflict has a positive impact on job stress.}

\subsection{Organisational commitment}

Organisational commitment is the employees' emotional linkage with the organization hence the parameters of this organizational behaviour variables are traced as the identification---the institutionalization and investment in the organizational goals (employees feeling that their goals and the organizational goals are alike), involvement----generation of a sense of affiliation with due performance and loyalty (Michael, Court \& Petal, 2009; Chen, Silverthorne \& Hung, 2006).

Gaither et al. (2008) illustrated that job stress and career commitment effected the job satisfaction, job satisfaction in turn combining its effect with the organizational commitment directly affected the work quality and turnover intention of pharmacists. However Chen, Silverthorne \& Hung (2006) found that stress does not directly affect organizational communication tough effective communication builds up the organizational commitment and increases job performance.

\section{H3: Organizational commitment has direct relationship with job satisfaction.}

\subsection{Job Performance}

There is an extant literature which states the job performance to be aligned with the personality characteristics. Rothmann \& Coetzer (2003) discussed the multi dimensional factor of job performance to be effected by the dispositional factors and the situational factors. The nature of job, organization and colleagues formulate the situational factor; while the dispositional factors comprise of personality factors like attitudes, goals and preferences which adjoin to an individual's tendency to react to situations in a predisposed manner. Defining performance as the output rate, Chen \& Silverthorne (2008) stated that the work related behavioural aspects including the job satisfaction, performance and stress can be traced to the integral personality type. Likewise, Chiu, Chien, Lin \& Hsiao (2005) concluded that nowadays the personality can be used as a predictor of turn over intention. The analysed tendency of job stress on job satisfaction and organizational commitment is higher for externals than internals thus it is found to act as the moderator between stress, satisfaction 
and turnover intention.

Individuals with external locus of control are less adaptive and more vulnerable to stress, due to which their performance decreases and they get dissatisfied than individuals with internal locus of control who are more composed and account themselves for their level of performance (Chen \& Silverthorne, 2008; Chiu, Chien, Lin \& Hsiao, 2005). Linking personality to job performance, satisfaction and stress Chen \& Silverthorne (2008) unveiled the same fact that along with the institutional factors 'locus of control' is the personality characteristic of need for reinforcement. Employees like 'accountants' who work under intense time and pressure frame attribute their performance to chance, power, reward and others if their locus of control is external. Rothmann \& Coetzer (2003) conceptualized the NEO personality Inventory and big five personality factors to predict the influence the pharmacist's job performance at the individual level. And Identified that the employability and performance of the candidates to be directly associated with their level of neuroticism i.e. the frequency and tendency by which an individual gets provoked and reacts to stressful situations, controls emotions and impulses, loses temper or gives irrational responses. Therefore 'Neuroticism' is the great predictor of job performance regarding stress and emotional stability. Wu (2011) mentioned the importance of dispositional variable 'Emotional intelligence' as an excellent moderator between employee stress-performance relationships which facilitates employees to transform and regulate their emotions in their social interactions and makes them more resilient and adaptable in the stress environment of heavy duty jobs.

\section{H4: Job stress negatively influences the job performance.}

\section{H5: Job demand negatively impacts the job performance.}

\subsection{Burnout}

Burnout is the consistent emotional pressure from the immediate environment which enforces an individual to lose all the energy, motivation and commitment to carry on a task satisfactorily. It is an immense reaction towards pressure arising from the role conflicts and job demand conflicts and its influence can be observed in the employees' physical and psychological distress. It is observed mostly as the end result of heavy demanding jobs across various fields like real estate, nursing, finance, teaching, risk management etc (Shropshire \& Kadlec, 2012).

\section{H6: Job stress has the positive relationship with Burnout.}

\subsection{Turn over intention}

Gaither et al. (2008) described this construct as disruption in the work as employees leave the jobs. Normally this is huge loss to the organization as the casted out employees informally acquire various special skills; they have the organizational knowledge and are mostly professional enough due to their experience at the organization. The volunteer turnover of a competent employee is a huge loss to the organization monetarily (sustained sales loss, training and recruitment cost loss and cost of selecting the new profile). This propensity to 
leave is also a result of reduced job satisfaction and low organizational commitment. Lower stress results in eventually meeting of job expectations and higher organizational commitment which ultimately lowers the propensity to leave.

\section{H7: Stress has a positive relationship with turnover intention.}

\subsection{Job Satisfaction}

Job satisfaction is the critical feeling about different facets of job and is normally originated from the past events. The determinants of job satisfaction are numerous among which the organizational compensation philosophy, degree of power distribution and centralization and individuals characteristics are of huge importance (Chen \& Silverthorne, 2008). Moncrief et al. (1997) explored the relationship of this construct with 'met expectations'. Job satisfaction is the effective feeling (favourable or unfavourable) of employee towards the job, which impacts job adversely or positively. Met expectations are the resultant prospects which turn out as expected during employment. Moreover the findings predicted that lower stress (lower conflict and ambiguity) results in more met expectations which makes employees more loyal, satisfied and committed due which the propensity of turnover reduces maximally.

Ismail, Yao \& Yunus (2009) theorized that high physiological stress triggered job dissatisfaction however psychological stress was not found to have any impact on job satisfaction. Inter relating the constructs of job satisfaction, psychological and physiological stress Ismail, Yao \& Yunus (2009) further asserted the construct of self efficacy theory. This theory says that a person high at self efficacy will be able to manage emotions and control the negative cognitive thoughts effectively which in turn will create a sound and satisfied wellbeing with better emotional and physical health.

H8: Job stress negatively influences the job satisfaction.

\section{Hypothetical Frame work of Job Stress}

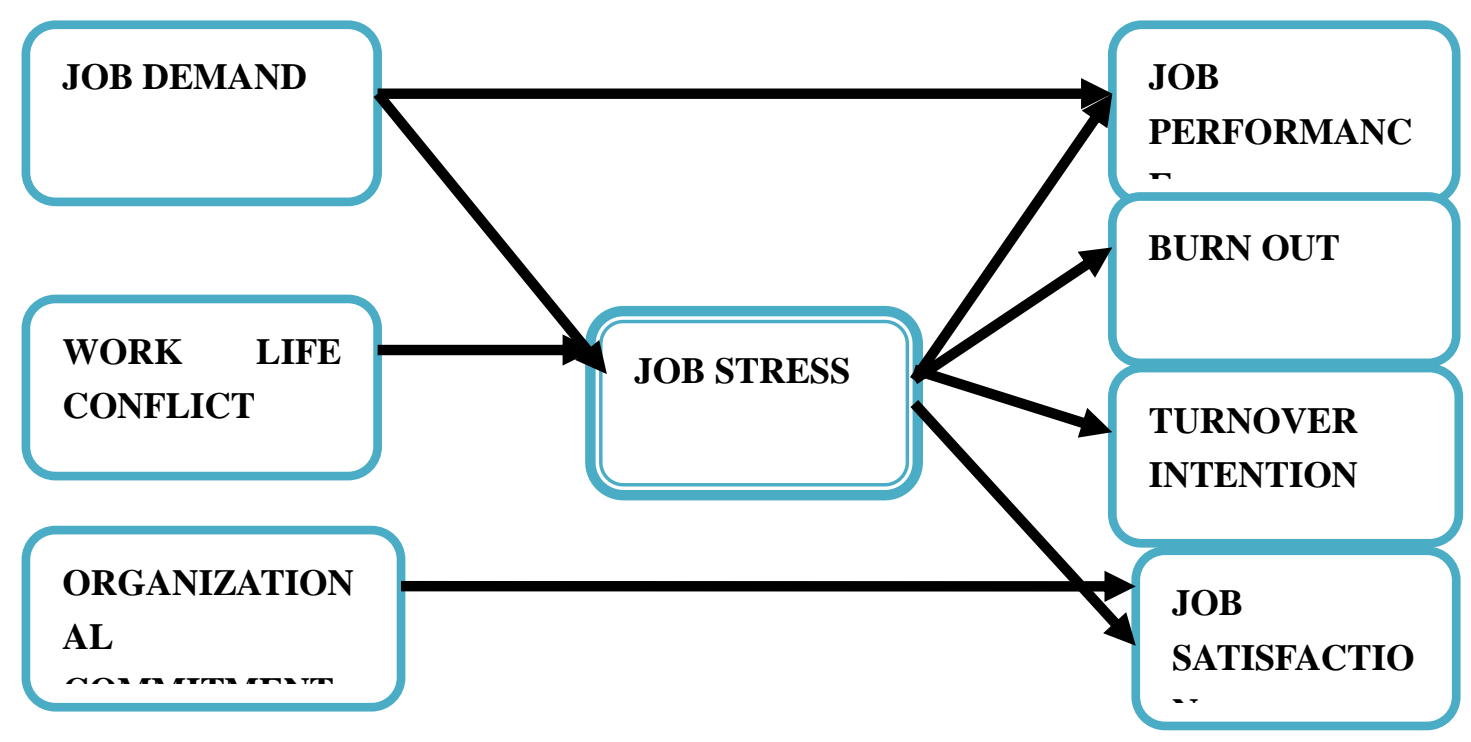

Figure 1: Structural model for STRESS IN BANKING INDUSTRY (private sector) 


\section{Research Methodology}

Rizwan et al. (2012) cited Creswell (1994) to illustrate the concept of descriptive studies; such studies are mostly conducted to explain a phenomenon of interest rather than making interpretations and judgments. The current study is descriptive in nature. Rizwan et al. (2012) further cited Kumar (2005) who stated that descriptive research is carried out to prove all the developed hypotheses regarding the observable fact. Thus such research is explanatory in nature and provides useful information about a situation.

\subsection{Sample/Data}

The concerned population for this research included the banking personals. Among which a sample of 230 individuals were selected to be the part of self administered questionnaire survey. Convenience sampling being the part of non probability sampling was utilized for this research. Mostly adapted during the initial phases of exploratory research; this sampling technique ensures efficient flow of worth full information. Simply this sampling technique focuses on obtaining relevant data from the people who are conveniently available (Sekaran $\&$ Bougie, 2010). It was made sure that the sample participants were working strenuously in the privatized banking sector so that they can better evaluate their working conditions.

\subsection{Instrument and Measures}

The questionnaire survey adapted for this research intended to measure the prospect factor of job stress; which results into counterproductive outcomes. Secondly this study was conducted to build a profile of respondents with specific characteristics which can be used further for different purposes.

The items taken into consideration were adapted from previously validated scales. The scales of job stress and organizational commitment were taken from (Mowday et al., 1979), Job performance was taken from (Bowra et al., 2011), job satisfaction scale was extracted from the work of (Konrad et al., 1999), Turnover intention was taken from (Cummann et al., 1979), Job demand and work life conflict were extracted from (Vohra, T. S., n.d.), while burn out was taken from (Vohra, T. S., n.d.; Gallimore, J., n.d.). The questionnaire had two distinct portions. Section 1 comprised of various demographic variables traced to the personal lives of the respondents like gender, age, education, status, children, number of children, name of the bank, years of experience, years worked at the present organisation and the level of management; while Section 2 included the latent constructs like job demand, work life conflict, organizational commitment, job performance, burnout, turnover intention, job satisfaction and job stress. All of these constructs in the questionnaire survey were measured against 5 point Likert-type scale ( $1=$ strongly agree to $5=$ strongly disagree) ; except the job stress in which respondents were asked to indicate the intensity of perceived job stress $(1=$ Always to 5= Never). 
Table 1: Scales of the Study

\begin{tabular}{|c|c|c|c|c|}
\hline No & Variable & Items & Reference & \\
\hline 1 & Job Demand & $\begin{array}{l}\text { 1. I am not able to meet up the demands of my } \\
\text { job. } \\
\text { 2. I experience excessive work load. } \\
\text { 3. I work for long hours, overtime and even on } \\
\text { holidays. } \\
\text { 4. I am not able to receive support from my } \\
\text { boss, colleagues and juniors. }\end{array}$ & $\begin{array}{l}\text { Vohra, } \\
\text { (n.d.) }\end{array}$ & . $\quad \mathrm{S}$. \\
\hline 2 & $\begin{array}{l}\text { Work Life } \\
\text { Conflict }\end{array}$ & $\begin{array}{l}\text { 1. I usually miss out quality time with my } \\
\text { family and friends because of pressure of } \\
\text { work. } \\
\text { 2. I am not able to receive good support from } \\
\text { my family members. } \\
\text { 3. My job requires travelling away from home. } \\
\text { 4. My supervisor does not support me in each } \\
\text { and every matter especially during } \\
\text { emergencies. }\end{array}$ & $\begin{array}{l}\text { Vohra, } \\
\text { (n.d.) }\end{array}$ & . S. \\
\hline 3 & Burn Out & $\begin{array}{l}\text { 1. I suffer from stress related diseases like } \\
\text { hypertension, obesity, diabetes, frequent } \\
\text { headaches. } \\
\text { 2. I am frustrated in carrying out my job } \\
\text { duties/responsibilities. } \\
\text { 3. I feel negative futile or depressed about my } \\
\text { job. } \\
\text { 4. I feel physically, emotionally or spiritually } \\
\text { depleted. } \\
\text { 5. My resistance to illness is lowered. } \\
\text { 6. My communication with my Boss, } \\
\text { colleagues, friends and family is } \\
\text { strained/nervous. } \\
\text { 7. The quality of my work is less than it should }\end{array}$ & $\begin{array}{l}\text { Vohra, } \\
\text { (n.d.) } \\
\text { Gallimore, } \\
\text { (n.d.) }\end{array}$ & . S. \\
\hline
\end{tabular}




\begin{tabular}{|c|c|c|c|}
\hline & & $\begin{array}{l}\text { be. } \\
\text { 8. I feel little enthusiasm for doing my job. } \\
\text { 9. I feel tired even with adequate sleep. } \\
\text { 10. My decision making ability seems less than } \\
\text { usual. }\end{array}$ & \\
\hline 4 & Job Stress & $\begin{array}{l}\text { 1. How often have you felt nervous and } \\
\text { "stressed" at job? } \\
\text { 2. How often have you found that you could } \\
\text { not cope with all the things that you had to } \\
\text { do? } \\
\text { 3. How often have you been angered because } \\
\text { of things happening outside your control? } \\
\text { 4. How often have you felt that difficulties } \\
\text { were increasing and you could not overcome } \\
\text { them? }\end{array}$ & $\begin{array}{l}\text { Mowday et al. } \\
(1979)\end{array}$ \\
\hline 5 & $\begin{array}{l}\text { Organization } \\
\text { al } \\
\text { Commitment }\end{array}$ & $\begin{array}{l}\text { 1. I would accept almost any type of job } \\
\text { assignment in order to keep working for this } \\
\text { organization. } \\
\text { 2. I feel very much loyal to my organizations. } \\
\text { 3. I feel proud to tell others that I am part of } \\
\text { this organization. } \\
\text { 4. I refer this organization to my friends as a } \\
\text { great place to work for. } \\
\text { 5. In the present circumstances its of little } \\
\text { chance that I leave this organization. }\end{array}$ & $\begin{array}{l}\text { Mowday et al. } \\
(1979)\end{array}$ \\
\hline 6 & $\begin{array}{l}\text { Job } \\
\text { Performance }\end{array}$ & $\begin{array}{l}\text { 1. My performance is better than that of my } \\
\text { colleagues with similar qualifications. } \\
\text { 2. I am satisfied with my performance because } \\
\text { it is mostly good. } \\
\text { 3. My performance is better than that of other } \\
\text { Bankers with similar qualifications in other } \\
\text { Banks. }\end{array}$ & $\begin{array}{l}\text { Bowra et al. } \\
(2011)\end{array}$ \\
\hline 7 & Job & 1. Overall, I am pleased with my work. & Konrad et al. \\
\hline
\end{tabular}




\begin{tabular}{|c|c|c|c|}
\hline & Satisfaction & $\begin{array}{l}\text { 2. Overall, I am satisfied in my current } \\
\text { practice. } \\
\text { 3. My current working situation is not a major } \\
\text { source of frustration in my life. } \\
\text { 4. Practicing this job meets my expectations. } \\
\text { 5. If I had to do it all over again, I would still } \\
\text { choose to work for the same organization. }\end{array}$ & (1999) \\
\hline 8 & $\begin{array}{l}\text { Turnover } \\
\text { Intention }\end{array}$ & $\begin{array}{l}\text { 1. I am emotionally callous about the } \\
\text { problems; I want to change my current } \\
\text { organization. } \\
\text { 2. I often think about quitting. } \\
\text { 3. I will probably look for a new job in the } \\
\text { coming futures }\end{array}$ & $\begin{array}{l}\text { Cummann et al. } \\
\text { (1979) }\end{array}$ \\
\hline
\end{tabular}

\subsection{Procedure}

As per the above mentioned criteria 230 respondents were selected from the city of Bahawalpur and Bahawalnagar. The questionnaire was circulated among the respondents; who were also told about the intent and scope of the study so that they appear confident and logical while solving the questions. A sum of 150 respondents was observed as authentic while the rest were discarded due to invalid responses. After this collection phase was over and the data was recorded into the data sheet of SPSS for analysis.

\subsection{Reliability Analysis}

The job stress questionnaire depicts the Cronbach's alpha of 0.819 which is more than the standard recommended value of 0.50 as stated by Nunnally (1970) and 0.60 by Moss et al. (1998) cited by Rizwan et al. (2012). This clearly states that all of the 38 items were reliable to monitor the job stress perceived by the banking sector's employees.

Table 2: Reliability of Measurements Instrument

\begin{tabular}{|l|l|l|}
\hline Scales & Items & Cronbach's Alpha \\
\hline Job demand & 4 & 0.688 \\
\hline Work Life Conflict & 4 & 0.806 \\
\hline
\end{tabular}




\begin{tabular}{|l|l|l|}
\hline Burnout & 10 & 0.851 \\
\hline Job Stress & 4 & 0.874 \\
\hline Organizational Commitment & 5 & 0.770 \\
\hline Job Performance & 3 & 0.764 \\
\hline Job Satisfaction & 5 & 0.897 \\
\hline Turnover Intention & 3 & 0.927 \\
\hline
\end{tabular}

\section{Results and Analysis}

\subsection{Profile of the Respondents}

Personal and demographic information of the respondents such as gender, age, children, number of children, education level, status, name of the organization, time elapsed at the job and total working experience is presented in the following table.

Table 3. Profile of the respondents

\begin{tabular}{|l|l|l|l|}
\hline & Category & Frequency & Percentage \\
\hline Variable & & & \\
\hline Gender & Male & 100 & 66.7 \\
& Female & 50 & 33.3 \\
\hline Age & $\begin{array}{l}20-25 \text { Years } \\
25-40 \text { Years }\end{array}$ & 34 & 22.7 \\
$40-60$ Years & 102 & 68.0 \\
Status & Single & 76 & 9.3 \\
\hline Children & Married & 74 & 50.7 \\
& Yes & 54 & 49.3 \\
\hline
\end{tabular}




\begin{tabular}{|c|c|c|c|}
\hline No of children & $\begin{array}{l}1-4 \\
5-8 \\
\text { none }\end{array}$ & $\begin{array}{l}44 \\
7 \\
99\end{array}$ & $\begin{array}{l}29.3 \\
4.7 \\
66.0\end{array}$ \\
\hline Education & $\begin{array}{l}\text { Inter } \\
\text { Bachelor } \\
\text { Masters } \\
\text { M Phil }\end{array}$ & $\begin{array}{l}7 \\
26 \\
104 \\
13\end{array}$ & $\begin{array}{l}4.7 \\
17.3 \\
69.3 \\
8.7\end{array}$ \\
\hline Name of the Bank & $\begin{array}{l}\text { Allied Bank } \\
\text { Askari Bank } \\
\text { Bank Alfallah } \\
\text { Habib Bank } \\
\text { Meezan Bank } \\
\text { Muslim Commercial } \\
\text { Bank } \\
\text { Silk Bank } \\
\text { Soneri Bank } \\
\text { United Bank }\end{array}$ & $\begin{array}{l}12 \\
5 \\
14 \\
9 \\
11 \\
80 \\
6 \\
5 \\
8\end{array}$ & $\begin{array}{l}8.0 \\
3.3 \\
9.3 \\
6.0 \\
7.3 \\
53.3 \\
4.0 \\
3.3 \\
5.3\end{array}$ \\
\hline $\begin{array}{l}\text { Years of Work } \\
\text { experience }\end{array}$ & $\begin{array}{l}\text { 1-10 Years } \\
11-20 \text { Years } \\
21-30 \text { Years } \\
31-40 \text { Years }\end{array}$ & $\begin{array}{l}124 \\
12 \\
10 \\
4\end{array}$ & $\begin{array}{l}82.7 \\
8.0 \\
6.7 \\
2.7\end{array}$ \\
\hline $\begin{array}{l}\text { Years worked at the } \\
\text { present organization }\end{array}$ & $\begin{array}{l}\text { 1-10 Years } \\
11-20 \text { Years } \\
21-30 \text { Years } \\
\text { 31-40 Years }\end{array}$ & $\begin{array}{l}128 \\
10 \\
9 \\
3\end{array}$ & $\begin{array}{l}85.3 \\
6.7 \\
6.0 \\
2.0\end{array}$ \\
\hline
\end{tabular}




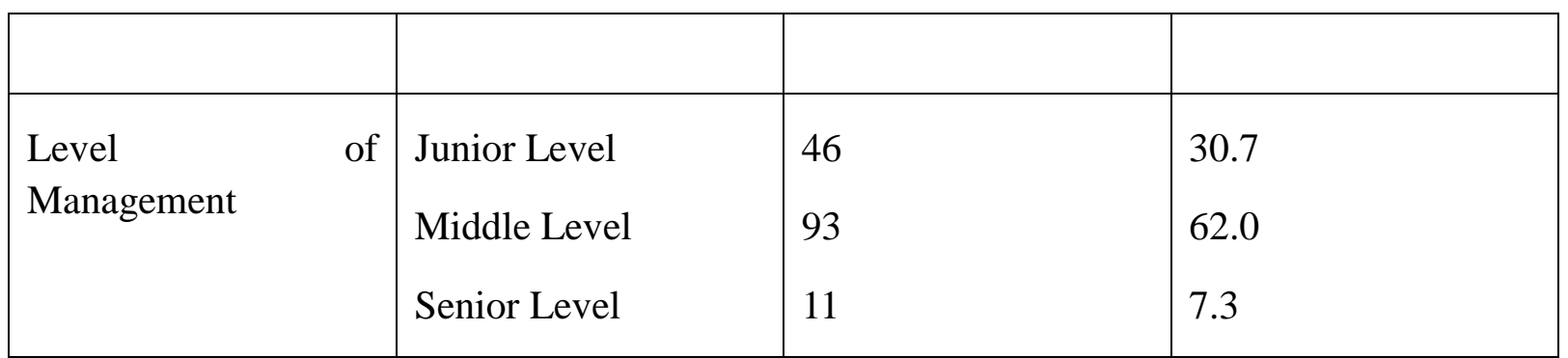

\subsection{Hypothesis Testing}

\subsubsection{Job Demand and Job Performance:}

While considering the significance between Job Demand and Job Performance, the results of the current study shows highly insignificant relationship between these two variables with $(\beta=0.053)$ and $(p>0.569)$. Based on these results, we reject H5 and conclude that the study did not find significant relationship of Job Demand and Job Performance.

\subsubsection{Job Stress, Job demand and Work Life Conflict:}

According to the results of the study, variables of Job Demand, Work life conflict and Job Stress have a significant positive relationship. Specifically, Job Demand has a significant positive relationship with $(\beta=0.410)$ and $(p<0.000)$ with job stress. That means the Job Demand contributes $41 \%$ to Job Stress. And Work Life Conflict has also a significant positive relationship with $(\beta=0.103)$ and $(p<0.256)$ with job stress. That means that Work Life Conflict contributes more than $10 \%$ to Job Stress. Results of the current study validate the H1 and $\mathrm{H} 2$ which means that we fail to reject our hypothesis.

\subsubsection{Job Stress, Job Performance, Burnout, Turnover Intention and Job Satisfaction:}

According to the results of the study, the both variables Burnout and Turnover have a significant positive relationship with Job Stress. Specifically, the Burnout has a significant positive relationship with $(\beta=0.659)$ and $(\mathrm{p}<0.000)$. That means the Burnout contribute more than $65 \%$ to Job Stress. Result of the current study validates the H6 which means that we fail to reject our hypothesis. Turnover Intention has also a significant positive relationship with Job stress $(\beta=0.536)$ and $(\mathrm{p}<0.000)$ that means it contributes more than $53 \%$.As a result, the current study validates the $\mathrm{H} 7$.

Analysis of the study has shown highly insignificant relationship between Job Stress and Job performance with $(\beta=0.040)$ and $(\mathrm{p}>0.668)$ which rejects $\mathrm{H} 4$ and conclude that there is no significant relationship of Job Stress and Job Performance.

Job stress and Job Satisfaction has a significant relationship with $(\beta=0.092)$ and $(p<0.226)$ which validate $\mathrm{H} 8$. 


\subsubsection{Organizational Commitment and Job Satisfaction:}

Regression estimates results show that variables Organizational Commitment and Job Satisfaction have a significant positive relationship with $(\beta=0.389)$ and $(\mathrm{p}<0.000)$. That means the Organizational Commitment contribute more than $38 \%$ to Job Satisfaction. The above results confirm $\mathrm{H} 3$ and we conclude that Organizational Commitment and Job Satisfaction has a significant positive relationship.

Table 4: Regression Results

\begin{tabular}{|c|c|c|c|c|c|c|}
\hline Hypothesis & Model Variables & Estimate & S.E. & C.R. & $\mathbf{P}$ & Results \\
\hline $\begin{array}{l}\text { H5 } \\
\text { H4 }\end{array}$ & $\begin{array}{l}\text { Job_demand } \longrightarrow \text { Job_P } \\
\text { Job_Stress } \longrightarrow \text { } \\
\text { Job_P }\end{array}$ & $\begin{array}{l}0.053 \\
0.040\end{array}$ & $\begin{array}{l}0.094 \\
0.071\end{array}$ & $\begin{array}{l}0.571 \\
.429\end{array}$ & $\begin{array}{l}0.569 \\
0.668\end{array}$ & $\begin{array}{l}\text { Not } \\
\text { supported }\end{array}$ \\
\hline $\begin{array}{l}\mathrm{H} 1 \\
\mathrm{H} 2\end{array}$ & $\begin{array}{l}\text { Job_demand } \\
\text { Job_Stress } \\
\text { WLC } \\
\text { Job_Stress }\end{array}$ & $\begin{array}{l}0.410 \\
0.103\end{array}$ & $\begin{array}{l}0.120 \\
0.118\end{array}$ & $\begin{array}{l}4.523 \\
1.140\end{array}$ & $\begin{array}{l}0.000 \\
0.256\end{array}$ & Supported \\
\hline $\begin{array}{l}\text { H6 } \\
\text { H7 } \\
\text { H8 }\end{array}$ & $\begin{array}{l}\text { Job_Stress } \longrightarrow \\
\text { Burnout } \\
\text { Job_Stress } \\
\text { Job_Stress } \\
\text { SAT }\end{array}$ & $\begin{array}{l}0.659 \\
0.536 \\
0.092\end{array}$ & $\begin{array}{l}0.046 \\
0.083 \\
0.070\end{array}$ & $\begin{array}{l}10.62 \\
1 \\
7.676 \\
1.217\end{array}$ & $\begin{array}{l}0.000 \\
0.000 \\
0.226\end{array}$ & Supported \\
\hline H3 & $\begin{array}{l}\text { Org_Comm } \longrightarrow \\
\text { SAT }\end{array}$ & 0.389 & 0.087 & 5.145 & 0.000 & Supported \\
\hline
\end{tabular}




\section{Macrothink}

H5

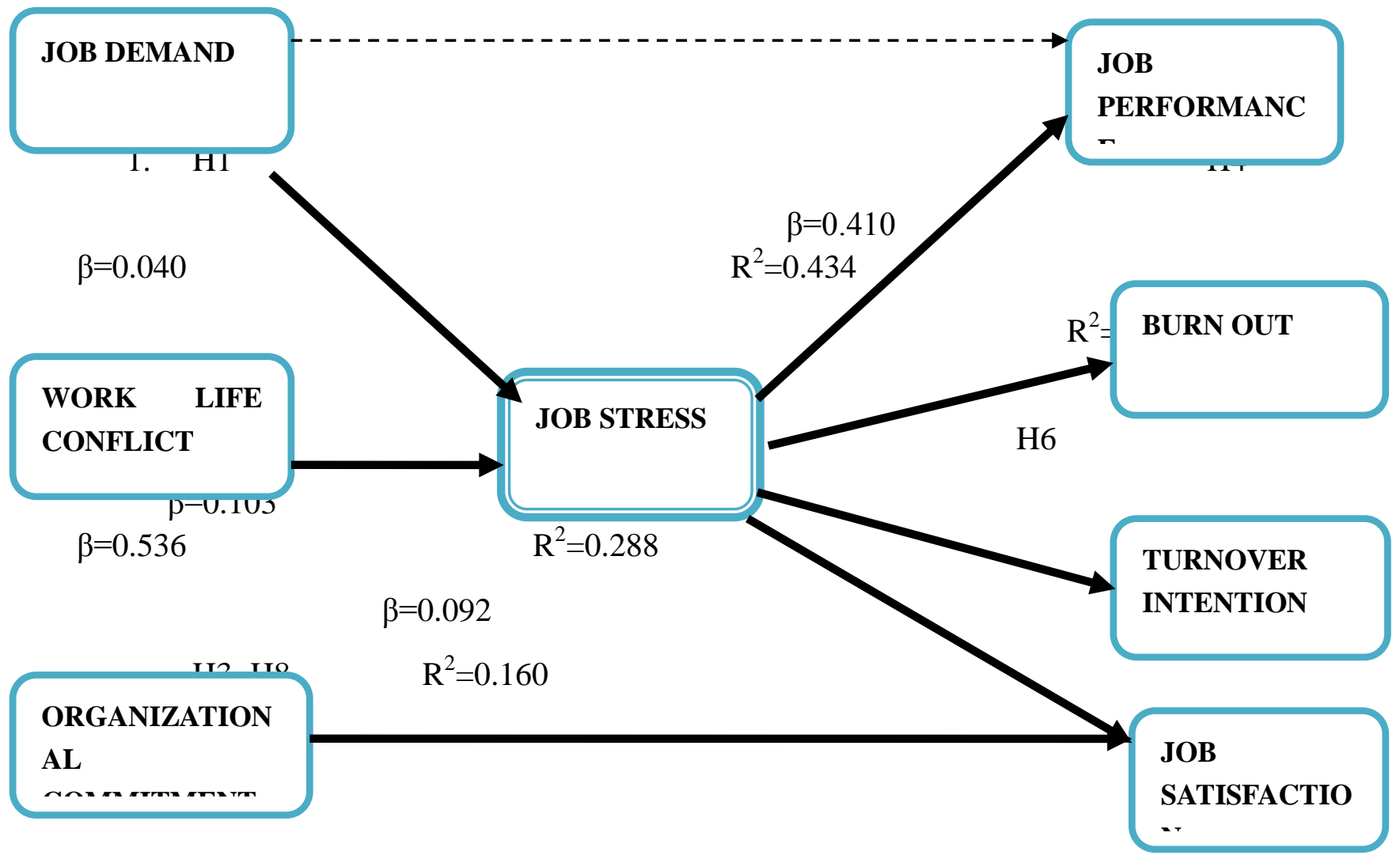

Figure 2: Structural Model Results

\section{Findings and discussion}

The Banking sector of Pakistan is one of the most evolving and stable sector which contributes substantially towards Pakistan's economy. The prime purpose of this study was to explore the relationship of stress causing factors for the heavy demanding working practises of a 'privatized banks' which hinder or contribute to an employee's progress one way or the other; in contrast to vast researches conducted for other institutions. The obtained results almost verified the established hypotheses in which to different degrees 'stress' was explored to be arising from the heavy job duties, work-life imbalance, varying satisfaction level towards the employment organization and these factors altogether emulsifying the pressure puff of 'stress' were discovered to be affecting the organizational commitment, performance and eventually resulting into burnout and intention to leave the banking field. All of these factors with their individual implications are discussed below.

The job demand and job stress are the only variable whose hypothetical relationship is found to be insignificant with job performance, this finding is found to be coherent with the possible reason given by Gaither et al. (2008) who argued that 'individual factors' possess the potential to buffer the impact of day to day job stress and psychological outcomes generated from the heavy job duties or extra role demands of a job performance. This fact is congruent 
with the work of Rothmann \& Coetzer (2003) who identified the individual personality factors like emotional stability (low neuroticism), extraversion, agreeableness, openness to experience and conscientiousness to influence task performance and creativity of managerial employees. Thus the bankers overall meet up the performance criteria because they accept their nature of job, manage their job demands and for their survival ultimately they manage their performance well, however during this work accomplishment they suffer from stress strains but this stress does not affect their job performance which is proved by the insignificant hypothetical relationship of job stress and job performance.

Previous studies confirm the impact of job stress on work life conflict, job satisfaction

(Fairbrother \& Warn, 2003; Ismail, Yao \& Yunus , 2009; Kim, Murrmann \& lee, 2009), job performance ,burnout and turn over intention (Shropshire \& Kadlec, 2012; Wu 2011; Chiang, Birtch \& Kwan, 2010) which is familiar to our research results. Our findings also declare these factors to be the strongest predictors of job stress.

Thus the results of job demand and work life conflict are found to exert significant influence on job stress. The heavy duty jobs of the bankers often requires them to meet the financial targets, work in an interactive environment and work beyond the normal working schedule, due to which they are normally assumed to be compensated huge but they are not as per the current compensation practices adopted by the private banking sector. Even if private sector banking employees are provided with resources to accomplish their hectic jobs, but still Lawrence \& Kacmar (2012) implied that the overwhelmed work demand and expectations from multiple roles result in job dissatisfaction and psychological stress. With reference to Social exchange theory; it is observed that high quality exchange association from the supervisor to the subordinate (resource provision, career development etc) influences the employees to reciprocate equally and effectively with a sense of obligation.

The norm of reciprocity in bankers is observed in the certain tradeoffs which the employees have to make like trade off between job involvement and physical and physiological unrest, quality family life and efficient work life, obligation towards job criteria and meeting self expectations, between commitment to job demand and surrendering by intending to leave. Thus the organization must implement initiatives for the work life balance by giving them liberty at flexible scheduling, empowerment and autonomy over work to boost up the creative energy and avoid talent depletion especially in the closing season's i.e. Monthly and yearly (June and December); when the bankers encounter frustration due to heavy workloads and long working hours. Based on the nature of banking industry in our results of the current study of the hypothesized relationships between the constructs of job performance, burnout, turnover intention, and job satisfaction are found to be the important variables which concurrently exert the stress strains in bankers and cause work force attrition. This study is consistent with the previous study of Shropshire \& Kadlec (2012) which stated that determinants of volunteer career change intention are highly associated with stress, job insecurity and burnout. 


\section{Mll Macrothink}

Journal of Public Administration and Governance

ISSN 2161-7104

2013, Vol. 3, No. 3

The results imply that banking practices show the prevalence of extensive working hours especially for the management positions like Branch Mangers \& Branch operations managers (who are key persons to accomplish the assigned targets in day to day Business \& operations), low decision latitude, unrealistic targets, low and slow growth opportunities, less rewards, leave problems due to staff shortage, extensive travelling with less allowances (travelling, accommodation allowances etc) to fulfil target in the network branches which are located far apart, less yearly bonuses/rewards due to forced appraisal rating and rigid promotion policies like most private banks just provide cash reward on passing JAIBP exam (Junior Associateship Institute of Bankers Pakistan) as compared to public sector banks which promote their employees. All of these factors are found to physically and emotionally deplete an employee's motivation, lower down the satisfaction due to which performance is affected and due to these stress causing factors mostly the unhappy employees of such banks suffer a lot and are in search of alternative options where they get reward for their efforts which results in high turnover among all private banks. This finding is in line with the findings of Michael, Court \& Petal (2009) who stated the behavioural outcomes of intense work involvement to be arising in the form of absenteeism and sick leaves, depression and frustration, lack of concentration and focus issues, work accidents, burnout and withdrawal behaviours like early retirements, and many other counterproductive stress strains.

The hypothetical relationship between organizational commitment and satisfaction is also found significant. As Chen, Silverthorne \& Hung (2006) found that stress does not directly affect organizational communication however effective communication builds up the organizational commitment and increases job performance. Moreover, the previous study of Michael, Court \& Petal (2009) states the 'affective commitment' of the employees as loyalty gained by physically and psychological rewarding them and aligning their needs with the organizational needs which in turn boosts their fair being and self worth. Therefore while relating the commitment of bankers with their performance level it is explored that the more the employees are loyal with their job the more are they generously physically and emotional get vested into their jobs which enhances their satisfaction level.

The managerial implication for this study entails that the loopholes should be covered by reviewing the current compensation(salary,perks, benefits, allowances) practices, performance rewards and promotion policies, meeting the desired staffing needs, and particularly evolving employees interpersonally through training and development i.e. cross functional training for job rotation, providing workshops on time management, effective communication, stress management and arranging interdepartmental workshops to evolve the in house talent. Moreover formulating the stress interventions like job redesign, restructuring and evaluation of job demand and control may result in feeling of competence due to which the performance will rise and it will prove itself to be a stress coping mechanism. As explained according to Chiang, Birtch \& Kwan (2010) that the job demand and job control with effective work life balance practices; increase the intrinsic value of the job and ultimately elevate stress. 


\section{Suggestions for future research}

The limitations acknowledged open up the opportunities for studies of the additional arenas. Future research should include the extended coverage of sample size, focus on inclusion of diverse geographical areas (other metropolitan cities and countries) and sample selection must be expanded across public sector banks and other diverse institutions like health services sector, IT industry, hotel \& catering industry, education sector etc. It will enhance the applicability and generalize ability of the findings for fruitful results. It is also suggested to carry the longitudinal design formats such as daily diary studies to check the level of stress at different points of time and in different situations. The practice of monotonous professions (like of bankers) becomes boring and tiring thus a detailed study of glossy factors in a job like compensation, advancement across the organizational hierarchy, availability of alternate jobs etc must be conducted to determine their impact in reducing the threshold of stress. On the organization's end the impact of training $\&$ development on reducing the stress dilemma can also be focused for future studies specifically for the jobs in which employees are supposed to be available over 9 to 9 and get physically and emotionally depleted. Also the human resource practices projected towards the individualized needs like compensation must be monitored in regulating stress and its impact over the organizational loyalty must be observed.

Research studies can also be focused on examination of stress over various development stages of a person. Like perceived level of stress is normally seen to vary among young \& old employees. Youngsters are normally supposed to have motivation, loyalty, and adaption to change, switch the jobs and react to the deteriorative circumstances as compared to the old ones who remain embed in their job throughout their life. The stress copying mechanisms should be highlighted varying with the demographic and personality variables.

\section{Limitations}

Although this study is useful for understanding the overinflated factors that cause stress at private banking sector and to observe its impact in the form of positive and negative behavioural outcomes (job performance, job satisfaction, turnover intention), a number of factors still limitize it.

Firstly, the geographical scope of this study was a small sample of about 150 employees working in private banks of Bahawalpur and Bahawalnagar. Due to such a small sample size the restricted result cannot be generalized across the whole population. Secondly, the homogeneity of sample confines its applicability over banking industry only. As this study is only limited to the investigation of job stress and its effects in private banking sector of Pakistan; due to this the public sector of banking industry is ignored which competes more severely over scare resources and where job stress is definitely embedded in various work place and non work place factors. Thirdly, some other constructs relevant to the individual prospects like employee's attitude, behaviour and personality traits i.e. locus of control, emotional intelligence, Big five personality traits (neuroticism, openness to experience, extraversion, agreeableness, conscientiousness) social support (leader member exchange relationships) and age are ignored; which can be investigated to predict the person to person 
variation of stress level. Furthermore, the hypothetical relationships considered in this research are verified through the cross sectional data and its of great chance that these relationships may change over time, therefore the research should be longitudinally carried out to observe the impact of job stress over varying time frames.

\section{References}

1. Chen, C., \& Kao, Y. (2011). The antecedents and consequences of job stress of flight attendants e evidence from Taiwan. Journal of Air Transport Management, 17, 253-255.

2. Chen, J., \& Silverthorne, C. (2008). The impact of locus of control on job stress, job performance and job satisfaction in Taiwan . Leadership \& Organization Development Journal, 29(7), 572-582.

3. Chen, J., Silverthorne, C., \& Hung, J. (2006). Organization communication, job stress, organizational commitment, and job performance of accounting professionals in taiwan and america. Leadership \& Organization Development Journal, 27(4), 242-249. doi: DOI 10.1108/01437730610666000

4. Chiang, F. F. T., Birtch, T. A., \& Kwan, H. K. (2010). The moderating roles of job control and work-life balance practices on employee stress in the hotel and catering industry. International Journal of Hospitality Management, 29, 25-32.

5. Chiu, C., Chien, C., Lin, C., \& Hsiao, C. Y. (2005). Understanding hospital employee job stress and turnover intentions in a practical setting: The moderating role of locus of control. Journal of Management Development,24(10), 837-855. doi: http://dx.doi.org/10.1108/02621710510627019

6. Creswell, J.W. (1994) Research Design: Qualitative \& Quantitative Approaches. London: SAGE Publications.

effects of role stress in frontline service jobs? Journal of Business Research 59(10-11), 1087-1093.

7. Fairbrother, K., \& Warn, J. (2003). Workplace dimensions, stress and job satisfaction. Journal of Managerial Psychology,18(1), 0268-3946. doi: DOI 10.1108/02683940310459565

8. Gaither, C. A., Doucette, W. R., \& Pederson, C. A. (2008). A modified model of pharmacists' job stress the role of organizational, extra-role, and individual factors on work-related outcomes.Research in Social and Administrative Pharmacy, 4, 231-243. Retrieved from www.sciencedirect.com

9. Ismail, A., Yao, A., \& Yunus, N. K. Y. (2009). Relationship between occupational stress and job satisfaction: An empirical study in Malaysia. The Romanian Economic Journal, 34(4), 3-29. 


\section{Macrothink}

Journal of Public Administration and Governance ISSN 2161-7104

10. Karatepe, O.M., Yavas, U., Babakus, E., Avci, T., 2006. Does gender moderate the

11. Kim, B. P., Murrmann, S. K., \& Lee, G. (2009). Moderating effects of gender and organizational level between role stress and job satisfaction among hotel employees. International Journal of Hospitality Management, 28, 612-619. doi: 10.1016/j.ijhm.2009.04.001

12. Lawrence, E. R., \& Kacmar, K. M. (2012). Leader-member exchange and stress: The mediating role of job involvement and role conflict. Journal of Behavioral \& Applied Management.

13. Michael, O., Court, D., \& Petal, P. (2009). Job stress and organizational commitment among mentoring coordinators. International Journal of Educational Management, 23(3), 266-288. doi: http://dx.doi.org/10.1108/09513540910941766

14. Moncrief, W. C., Babakus, E., Cravens, D. W., \& Johnston, M. (1997). Examining the antecedents and consequences of salesperson job stress. European Journal of Marketing, 31(11/12), 786-798.

15. Moss, S., Prosser, H., Costello, H. (1998). Reliability and validity of the PAS-ADD Checklist for detecting psychiatric disorders in adults with intellectual disability. Journal of Intellectual Disability Research. 42, 173- 183.

16. Nunnally, JC. (1970). Introduction to Psychological Measurement. New York: McGraw-Hill.

17. Rizwan, M., Gillani, S. U. A., Azhar, M. S., Mir, I. A., Saboor, F., \& Jan, M. A. (2012). Incorporating locus of control in technology acceptance model: A study from pakistan. American Journal of Scientific Research, (78), 61-83. doi: ISSN 2301-2005

18. Rizwan, M., Tariq, M. A., Hussain, S., Rashid, R. M., Hussain, M. S., \& Khawar, I. H. (2010). Antecedents of job stress and its impact on job satisfaction. Asian Journal of Empirical Research,3(2), 175-190.

19. Rothmann, S., \& Coetzer, E. P. (2003). The big five personality dimensions and job performance.SA Journal of Industrial Psychology, 29(1), 68-74.

20. Shropshire, J., \& Kadlec, C. (2012). I'm leaving the it field: the impact of stress, job insecurity, and burnout on it professionals. International Journal of Information and Communication Technology Research,2(1), 6-16. Retrieved from http://www.esjournals.org

21. WU, Y. (2011). Job stress and job performance among employees in the Taiwanese finance sector: The role of emotional intelligence. SOCIAL BEHAVIOR AND PERSONALITY, 39(1), 21-32. doi: 10.2224/sbp.2011.39.1.21

22. Rothmann, S., \& Coetzer, E. P. (2003). The big five personality dimensions and job performance.SA Journal of Industrial Psychology, 29(1), 68-74.

23. Sekaran, U., \& Bougie, R. (2010). Research methods for business: A skill-building 
ed.).

Wiley.

Retrieved

from

http://ebooks4us.org/2013/04/download-research-methods-for-business-5th-edition-by -uma-sekaran/ 